\title{
Factors Affecting Cattle Production in Puntland State of Somalia: A Case Study of Nugaal Region
}

\author{
Said M-Shidad Hussein \\ Master of Science in Development Studies \\ Jomo Kenyatta University of Agriculture and Technology, Somalia
}

\author{
Willy Muturi., PhD \\ School of Business. Jomo Kenyatta University of Agriculture \\ and Technology, Nairobi-Kenya
}

\author{
Hellen Mberia., PhD \\ COD-Social Sciences \& Humanities Department \\ Jomo Kenyatta University of Agriculture and Technology, Nairobi- \\ Kenya
}

\begin{abstract}
As one of the primary milk and meat producing livestock species, cattle contribute greatly to food security in Somalia. Cattle account for $25 \%$ of milk production and $24 \%$ of exportation income in Somalia. However, cattle population has drastically been decreasing in northern Somalia including Puntland for the last 25 years. As reflection of cattle situation in Somalia, over $90 \%$ of cattle population in Puntland was claimed by diseases and droughts during 19922004, particularly 2003-4. Today's surviving population is $95 \%$ less than that of 1991 or 2001 . The objective of the research was to determine factors that affect cattle production in Nugaal region of northeastern Somalia. The research was qualitative and quantitative in nature. The target population was the cattle-herding community in Nugaal region. Data captured were analyzed by the usage of Statistical Package for Social Science to determine the recent trends in the cattle population; the extent of the effects of the affecting factors; the result of the effects; and the view of the cattle-herding community on the current situation of the lifestyle. Descriptive statistical results suggested that critical insufficient feed supply in pasture, fodder, and water; lack of dependable cattle herders; diseases and lack of veterinary interventions are the factors that primarily affect the cattle welfare and numbers.

Keywords: Cattle, breed, production, Nugaal Region
\end{abstract}

\section{Introduction}

The cattle are one of the primary milk and meat producing livestock species in Somalia with others include goats, sheep, and camel. The role of cattle in food production and food security is very historic in Somalia as even some social scientists tend to suggest that the ancestors of the living Somalis were in regard of 'privileged relationship' between them and cattle. With background reflections, we can fully understand what cattle socioeconomically mean for the Somalis. Cattle herding has been the primary economic activity of the Somali society at the beginnings of the Somali history. Researchers on food production history in the Somali peninsula at particular and in the Horn of Africa at general have found that people in Somalia had been practicing cattle breeding from 7000 years ago onwards. Moreover, a series of rock paintings in northern Somalia show that the cattle was herded at least from 5000

The current issue and full text archive of this journal is available at http://jraspublications.org/index.php/JRAS/issue/archive Journal of Research in Administrative Sciences (JRAS)

VI(I), 13-16, ISSN: 2664-2433 years ago towards. The cattle were the most important species among the animals that the people painted on the walls of caves.

These linguistic and archaeological findings are supported by ancient records. Both the ancient Sumerian Iraqis and Egyptians mentioned (over 4000 years ago and 3500 years ago respectively) the cattle as animals attached to special importance in northern Somalia. The camel has just joined the cattle for economic importance by the few centuries prior to the birth of Jesus. However, Al-Mas'udi of Baghdad reported nearly eleven centuries ago that the cattle were still the leading economic resource in vast area south of Muqdisho or Mogadishu. In our time, Somalia usually ranks number 8 in Africa for cattle population per country. According to estimations of 1988 and 1998, the largest cattle population in central and northern Somalia were 
herded in the Northeast (Puntland) with around half million heads in the state by the latter estimation. By the estimation of 1998, cattle population in Somalia was 4,609,250 heads.

\section{Statement of the Problem}

Despite the historical economic role of the cattle in Somalia, the numbers of the animals have been decreasing for the last 25 years as indicated by available statistics. For example, according to Puntland Development Research Center (PDRC) the cattle number of late 2003 in Puntland were $74 \%$ less than that of 2001 and the loss remained to occur increasingly until late April 2004, at least. As further indication of the decline, there has been no single cow brought to the livestock markets of Puntland including Garowe city, the capital of both Puntland state and Nugaal region, for beef production and for any other kind of trade at least from 2007 onwards, according to records of Garowe Municipality. These data indicate that cattle production has fallen drastically. To reverse the trend, there is a need to know what is actually causing the problem, and hence this research.

The objective of the research: The objective of the research was to determine the effect of fodder and water supply, and labor and veterinary services availability on the cattle production in Garowe-centered Nugaal region of northern Somalia.

Target population: Cattle-rearing population of Nugaal region holding at least 10 heads of the animals was targeted through population census approach. This population has long been reduced to around 82 households by the negative changes. Data were however collected from 74 families $(90 \%)$ as the only members available for the questionnaire.

The conceptual framework: The conceptual framework was built on these hypothesized variables as following:

1) Independent Variables:

Fodder supply: amount, varieties

Water supply: amount, sources

Labor availability: number of herders

Veterinary services: practitioners, treatments

\section{2) Dependent Variable:}

Cattle production: numbers, breeds

Standards of cattle needs in these resources, particularly fodder and water supplies, should be set out. According to Rasby (2016), water requirements for cattle depend on four basic conditions: body weight, environmental temperature, stage of production (such as lactation, or fetal growth), and amount and type of fodder consumed. For example lactating cows of $450 \mathrm{~kg}$ of body weight can need around 75-91 liters of water per day for themselves and another 1938 liters for their calf in high temperature. Such cows then need 112 liters in average. Likewise, a cow with body weight of $450 \mathrm{~kg}$ needs to eat $13.5 \mathrm{~kg}$ per day and thus 405 $\mathrm{kg}$ per month in average, according to Pedretti (2013).

Usually, a tropical cow needs to drink 50 liters of water per day for herself (not including water for feed production and evaporation). In Somalia, a lactating cow with about $290 \mathrm{~kg}$ of body weight needs 50-70 liters of water while nonlactating cow needs half of that water. Such cows need 7 $10 \mathrm{~kg}$ of forage per day. At least two herders should look after 50 heads of cattle in the country. Veterinary services also affect the survival of cattle herding system. There are great challenges preventing to meet these requirements for these resources. Because of shortages in labor and other resources, the old system of rearing the cattle is in disarray. Three forms of cattle herding options are adopted today in Somalia. First, some families still remain in the mobile way of cattle herding, going after the pasture. Second, others adapted to sedentary form by holding few animals, mostly less than 10 heads, and keeping them at the village. Third, others mix the two forms. They use the public rangelands when forage is available and bring the animals back into a farm when it is not.

\section{Methodology}

The research was qualitative and quantitative in nature. Survey questionnaire, interviews, direct research, and review of exiting records were used as research instruments. Besides follow-up interviews with some of the questionnaire respondents, around 20 well-versed interviewees consisting of experts or knowledgeable persons in livestock statistics, and cattle herders from the five regions of Puntland were also interviewed.

\section{Findings \\ Cattle numbers in Puntland and particularly in Nugaal region}

Most of the available reports such as WSP (2000) and FAO (2004) on cattle population in Somalia generally and Puntland particularly supposed a steady yearly percentage increase of all livestock species of which the cattle's one is 1.6 times for 1988-1998 based on extrapolation approach. For instances, the cattle population of Puntland was estimated 271, 310 heads in 1988 so it was assumed to be 434,069 heads in 1998. That approach would make today's cattle population in Puntland around 1,111,300 heads and that of Nugaal region about 57,000 heads.

But the realistic case is very different from that one. The problem is that, as noted by FAO researchers themselves, droughts and diseases were not taken into account. Because of these gaps, these works lent little confidence to these estimations of theirs. In fact, most of the cattle regarded for 1988-1998 were claimed by recurring droughts and epidemic diseases of 1992-2004. One study (PDRC, 2004) found that by late $200374 \%$ of the cattle were lost to the drought. Interviewed cattle herders and experts added to that by April 2004 over 90\% of the animals. Another drought in 2010 and the ongoing devastating one have put the cattle of Puntland in a condition of pending extinction. In fact, around 20 well-versed interviewees consisting of experts of livestock statistics and cattle herders from the five regions of Puntland emphatically state that the presentday cattle in Puntland are even less than 5\% of that of 2001 or 1991. The examples that can support their view include that $88 \%$ of the cattle population in Puntland was owned by northern Mudug according to the estimations of 1988 and 1998. But according to interviewees, there are only some hundreds of those cattle in that region today. Nugaal is one of the four places that used to breed the largest number of cattle in the state with Nugaal has currently the highest number of cattle in the state because of its better water supply and cattle-favored grass rangelands.

Moreover, the descriptive finding on the following table has very important piece of information for it is giving us the picture of surviving cattle population in Nugaal Region. 
Cattle numbers of only 19 families are over 50 heads, and by follow-up no family even reported that his cattle number exceeds 80 animals and even few of them have cattle reaching that particular number. Cattle numbers of 15 families are between 40 and 49 . Similarly, Cattle numbers of 28 families are between 20 and 29; whilst 7 families head between 30 and 39; and only 5 families hold 10 to 19 animals. This generally means that cattle population held by the respondents is somewhere around 3000 heads. With that, according to the interviews with the respondents, these respondents own over $95 \%$ of the cattle population in Nugaal region. Therefore, the maximum number of cattle held in Nugaal at the time of the interview can be 3,500 animals while a high number of that is claimed by the current drought after the data were collection. This means that just several thousands of cattle heads can be expected to be surviving in Puntland today.

Table 1: Number of Cattle per Family in Nugaal

\begin{tabular}{ccc} 
Number of cattle & Frequency & Percent \\
\hline $10-19$ & 5 & 6.7 \\
\hline $20-29$ & 28 & 37.8 \\
\hline $30-39$ & 7 & 9.5 \\
\hline $40-49$ & 15 & 20.2 \\
\hline $50+$ & 19 & 25.7 \\
\hline Total & $\mathbf{7 4}$ & $\mathbf{1 0 0 . 0}$
\end{tabular}

\section{Effects of the variables on cattle numbers in Nugaal}

Fodder Supply: In descriptive analysis, seventy one respondents (96\%) stated that fodder shortage is the most difficult obstacle to cattle well-being and increase in number. Seventy two respondents $(98.6 \%)$ agreed that the traditional pasture does not produce forage that can closely feed the animals anymore. In the supportive interview, cattle pastoralists stated that even in the wet seasons the animals are less-fed because of lack of grass. The results also show that $95 \%$ of the respondents see that the current Situation of cattle herding is unsustainable so they would prefer to change it to more controllable or settled system.

Water supply: Sixty four respondents (86\%) strongly disagreed or just disagreed that there is sufficient free water for the cattle. Only $13.5 \%$ of the respondents agreed that sufficient free water is available for their water.

Labor availability: Seventy one of the respondents (96\%) disagreed that their cattle are herded by enough number of herders. Forty three (58\%) stated that they use hired workers that are not dependable but need to be assisted and supervised by the owner. Sixty five or $88 \%$ of the respondents stated that even these hired workers are not always available.

Veterinary services: The respondents $100 \%$ agreed that they use always only their own experience and money to treat cattle diseases. Around 53\% of them agreed that they consult by payment with paravets for bad conditions of animal ailment. They similarly $100 \%$ stated that they lose number of cattle to diseases in every year.

Generally, a study on macro-economy of Puntland (PDRC et al., 2004) and another one on Somali Galbeed, the Somali region in Ethiopia (Devereux, 2006) found that shortages in supplies of fodder, water, labor, and veterinary services severely de-stock the animals in the two regions respectively.

\section{Cattle Breed}

The respondents in the region indicate that they herd one cattle breed. This is understandable for the cattle in the Somali region are mainly grouped as Somali shorthorn Zebu or small Zebus of the Somaliland. The main breeds are Gasara, Garre, and in less significance Booran, in the south; and North Somali in the north. The cattle raised in Puntland belong to North Somali. Despite the fact that the small Zebus of the Somali are less weigh $(290 \mathrm{~kg}$ for average cow) and less milch (2.5 kg per day, with fat content of $5.4 \%$ ), this does not mean that the animals are substandard because they have rather traditionally been selected for survival throughout hundreds of generations and not for productivity (FAO, 2004).

\section{Conclusion}

The results show that the cattle number has drastically been deteriorating in Puntland during the last 25 years and that condition is in continual course. The reasons of such deterioration are shortages in pasture supply because of environmental degradation with recurring droughts; shortages in water supply because of lack of water management with the droughts; shortages in labor supply because the young generation have lost confidence and will in pastoralism lifestyle; and shortages of veterinary services because of absence of the required human and financial resources. Overall picture indicates a condition of pending failure in cattle-rearing pastoralism at anywhere in north of Shabeelle valley in the south of the country. In that vast land, cattle are in fading condition. The condition actually mirrors today's situation of pastoralism lifestyle in Somalia. By judgement of the researcher, who has long intimately been observing the situation, the case of other livestock species is not much better than that of the cattle. The results of the research also reflect questions and even gaps that need further researches to be carried out. For example, the interviewees were promptly pointing out that the problem primarily emanate from absence of functioning government role and regulations. FAO (2004) and African Development Bank (2013) hold the view also. Most of the respondents stated that they would prefer a settled pastoralism but they can't have land for their animals due to security problems and the absence of effective law and order. The results, in fact, reflect more questions. For instance, is it making sense to think about betterment of pastoralism situation without dealing seriously with the problems of institutional shortcomings and the environmental degradation?

\section{Recommendations}

Realization of saving the future of cattle and pastoralism generally would call for different types of tasks by the Somali government and private sector.

Government: The government should:

- Introduce and operationalize, determinedly, a culture and system of community land management which can allow appropriate fodder planting and stocking for long term use. 
- Encourage and develop establishment of settled pastoralism creating a pilot program for encouragement.

- Take an approach of adopting and educating that pasture shortages, land male-management, environmental degradation, and droughts are interconnected problems, and the droughts are not caused only by less rainfall but also by lack of land management and of environmental services.

- $\quad$ The government should also encourage and assist a system of community water management; establish safe, small dams at the flood plains of seasonal rivers (togs) with regulations and technical advancement to provide water management mechanism, agricultural production growth, and environmental protection technique.

- Reduce livelihood vulnerability and unnecessary herding burden by effective rural development programs to keep the young generation in herding job.

- The government should allocate a certain budget for animal health services for more trained vets and paravets, research on diseases, and treatment of the diseases.

Private sector: Since private sectors' role in development and positive collaboration with government efforts is necessary, the sector should avoid undoing or illegal privatization of more-favored public rangelands; seek investing and the reversing the degradation in lessfavored areas for agricultural development; introduce and utilize solar energy for animal watering, and irrigation for fodder and small mixed farming, bearing in mind that irrigation causes salinization.

\section{Suggestion for Further Research}

The researcher sees that urgent researches to be undertaken on the following areas:

The critical gap between the findings of this research and the existing records on the cattle population of northeastern Somalia (Puntland);

The best ways to change the traditional Somali pastoralism to settled one;

The best ways to control the sweeping environmental degradation and desertification in Somalia;

\section{References}

i. African Development Bank Group. (2013). Somalia: Country Brief. P. 4 and Annex 6.

ii. Al-Mas'udi. (1982), [first 935]. Muruuj Ad-Dahab wa Macaadin al-Jawhar. pp. 330, 338-9.

iii. Devereux, S. (2006). Vulnerable Livelihoods in Somali Region, Ethiopia. Brighton: Institute of Development Studies. pp. 26-47, 192.

iv. Food and Agriculture Organization of the United Nations (FAO) with the World Bank and European Union. (2004). Somalia: Toward A Livestock Sector Strategy. pp. 5-29.

v. Food and Agriculture Organization of the United Nations (FAO). (2016). Catalogue on Somalia: Somalia exports 5.3 million animals in 2015 . www.fao.org/somalia/news/detailevents/en/e/410266/ accessed Aug. 152016. vi. FAO. (2015). Catalogue on Somalia: Somalia registers record exports of 5 million livestock in 2014. www.fao.org/news/story/en/item/283777/icode

vii. Gutherz, X. and Luc J., eds. (2011). The Decorated Shelters of Laas Geel and the Rock Art of Somaliland. Montpellier, France. P. 18.

viii. Kramer, S. (1963). The Summerians, their History, Culture and Character. New York. pp. 276.

ix. Puntland Development Research Center. (2004). Macro-Economic Analysis in Puntland: Draft Report Funded by UNDP/World Bank and implemented by PDRC. Garowe. pp. 9-13.

x. Ministry of Planning and Statistics of Puntland. (2003). Garowe: Puntland Facts and Figures.

xi. Ministry of Planning and International Cooperation of Puntland. (2007), $3^{\text {rd }}$ edition. Puntland Facts and Figures. Garowe. p.6.

xii. Pedretti, J. (2013). Sprouted Barley Fodder: A Revolution in Animal Feed? https://mosesorganic.org/farming/farmingtopics/livestock/sprouted-barley-fodder-a-revolutionin-animal-feed/, accessed Sep. 15, 2016.

xiii. Rasby, R., (2016). Producer Question from 2016: How much water cows drink per day. beef.unit.edu/amounts water cows drink, accessed Sep. 4, 2016.

xiv. Said, H., (2011). Long Term Solutions for Drought Prevention in Somalia. www.shahid.net.

xv. Sprinkle, J. and Derek B. (2004). How many animals can I graze on my pasture? determining carrying capacity on small land tracts. http://extension.arizona.edu/sites/extension.arizona.e du/files/pubs/az1352.pdf. accessed Sep. 15, 2016.

xvi. Garowe Municipality. (2013). Statistical Abstract of Garowe Municipality. Garowe. p. 40.

xvii. WSP Somali Programme. (2001). Rebuilding Somalia: Issues and Possibilities for Puntland. London: WSP International through Haan Associates. pp. 99-101. 